\title{
気門封鎖剂によるタバココナジラミ（カメムシ目：コナジラミ科）の 定位打よび交尾阻害効果について
}

\author{
杖田 浩二* \\ 岐阜県農業技術センター
}

Inhibitory Effects of Spiracle-Blocking Insecticides on Courtship and Orientation in Sweetpotato Whitefly, Bemisia tabaci (Hemiptera: Aleyrodidae). Hirotsugu TsuedA* Gifu Agricultural Technology Center; 729 Matamaru, Gifu 501-1152, Japan. Jpn. J. Appl. Entomol. Zool. 63: 155-162 (2019)

\begin{abstract}
The sweetpotato whitefly, Bemisia tabaci (Gennadius) (Hemiptera: Aleyrodidae), is a notorious agricultural pest worldwide. In this study, the inhibitory activities of several spiracle-blocking insecticides on its orientation and courtship were investigated to identify an effective control agent against this pest. The numbers of orientated adults, courting pairs, and eggs were found to decrease on tomato plants that had been sprayed with decanoyloctanoylglycerol, safflower and cotton oil, or rape seed oil. Furthermore, when virgin female and male adults were released on tomato plants, the progeny sex ratio was higher (i.e., a higher percentage of males) on the plants that had been sprayed with decanoyloctanoylglycerol or safflower and cotton oil than on the corresponding control plants. Under greenhouse conditions, a cohort of tomato plants that had been sprayed with 500-fold diluted decanoyloctanoylglycerol four times every 10 days had fewer whitefly adults, lower numbers of eggs and larvae, and a higher sex ratio than the control plants. These results indicate that spiracle-blocking insecticides containing liquid oil, decanoyloctanoylglycerol, safflower and cotton oil, and rape seed oil can inhibit orientation and courtship in B. tabaci and allow this pest species to be maintained at a low density.
\end{abstract}

Key words: Spiracle-blocking insecticides; inhibitory effect; orientation; courtship; Bemisia tabaci

\begin{abstract}
緒
言

タバココナジラミ Bemisia tabaci (Gennadius) (カメムシ 目：コナジラミ科) は，熱帯から亜熱帯にかけて分布する 農業害虫である。本虫の食性は広く, 600 種以上の寄主植 物が報告されている (Oliveria et al., 2001)．本虫の繁殖力 は高く，施設内では各発育ステージからなる安定した個体 群を形成する。そのため, 施設栽培の野菜類や花卉類で は，深刻な被害が発生しやすい。本虫は，吸汁による生育 阻害，排泄物に起因するすす病による光合成能力の低下 (Hussey et al., 1958; Yee et al., 1996)，カボチャ（Cucurbita maxima Duchesne ex Lam.) の白化症 (Yokomi et al., 1990) やトマト (Solanum lycopersicum L.) の着色異常果 (Schuster et al., 1990；松井, 1992）といった障害を引き起こす. さら に本種はべゴモウイルスを主とする各種植物病原性ウイル スの媒介虫でもあり（Brown and Bird, 1992；Brown, 2000）, 各国で問題となっているトマト黄化葉巻病（病原ウイル ス, Tomato yellow leaf curl virus； TYLCV）やキュウリ退
\end{abstract}

緑黄化病 (病原ウイルス, Cucurbit chlorotic yellows virus; CCYV）を引き起こす. タバココナジラミ種内には，形態 的な差は認められないものの, 寄主適合性やウイルスの媒 介能力の差などから, 少なくとも 24 種類以上のバイオタ イプが存在すると考えられている (Costa and Brown, 1991; Bedford et al., 1994; Perring, 2001). 現在, わが国には在来 のものを含む 4 つのバイオタイプが確認されているが (本 多, 2005), 農業生産に打いて問題となるものは, バイオ タイプ B および Q である. 両バイオタイプはともに侵入 害虫であり，それぞれ 1989 年と 2005 年に国内で初確認さ れ (大戸, 1990; Ueda and Brown, 2006)，その後急速に分 布を拡大した (本多, 2008). 近年の研究では, タバココ ナジラミは少なくとも24の遺伝的に異なる隠蔽種の複合 であると報告されているが (Dinsdale et al., 2010; Xu et al., 2010; De Barro et al., 2011), 本稿ではバイオタイプとして 扱う。な拉，バイオタイプ B は Middle East-Asia Minor 1, バイオタイプ Q は Mediterranean と同一である.

タバココナジラミは，多くの殺虫剤に対して感受性が

*E-mail: tsueda-hirotsugu@pref.gifu.lg.jp

2018 年 11 月 25 日受領 (Received 25 November 2018)

2019 年 6 月 30 日登載決定 (Accepted 30 June 2019)

DOI: 10.1303/jjaez.2019.155 
低く，なかでもバイオタイプ $\mathrm{Q}$ はバイオタイプ $\mathrm{B}$ の防 除に有効であったピリプロキシフェンやネオニコチノイ ド系殺虫郕に対する感受性が低いことが報告されている (Horowitz et al., 2003; Dennehy et al., 2010).また, 中国や スペイン，わが国の各地域では，これまで優占的であっ たバイオタイプ Bが減少し，対照的にバイオタイプ Q が 増加して優占的となるようなバイオタイプの変遷現象が 報告されている (Simón et al., 1999; 樋口ら, 2007; 大井田 ら, 2007; Chu et al., 2010)。殺虫剛感受性の差は，個体群 中のバイオタイプ B と Q の生存率に影響するため, この 変遷現象に影響している要因の 1 つであると指摘されてい る (Crowder et al., 2010; Sun et al., 2013)。バイオタイプ Q の比率が高まれば，効果的な殺虫劑が限定されるため，殺 虫剤による防除は困難になることが予想される。特にバイ オタイプ B には高い殺虫効果を示すがバイオタイプ Q に は効果の低い殺虫牏を使用すると，バイオタイプ Qへの 変遷現象を助長することが指摘されている(杖田・妙楽, 2015)。このような変遷現象を回避するためには, 両バイ オタイプに同程度の効果を示す殺虫剤の選択が重要とな る.

近年，アセチル化グリセリドを植物に散布すること で，タバココナジラミ成虫の定位忌避や求愛行動を阻害 する効果が得られることが報告されている (Kashima et al., 2014）。アセチル化グリセリドによる求愛行動の阻害は, タバココナジラミの雌雄成虫が葉を振動させて発する音響 信号による交信が正常に行えないことに起因するとされ， バイオタイプ B と Q ともに交尾が正常に行われないこと が報告されている (Kashima et al., 2016)．タバココナジラ ミは半数倍数性であり，受精卵から雌が，未受精卵から雄 成虫が発育する (Byrne and Berrows, 1991)。そ活のめ, ア セチル化グリセリドの散布による交尾阻害は，未受精卵か ら発育する雄の子孫の増加につながり, 性比（雄率：雄／ (雄十雌)）の上昇による繁殖率の低下につながることが期 待されている (Kashima et al., 2016). アセチル化グリセリ ドによる交信阻害のメカニズムは十分に解明されていない が，葉に付着したアセチル化グリセリドの影響により，タ バココナジラミ成虫が葉を振動させる音響が正常に伝達し ない，もしくは本剤を使用しない場合と比べて変化する可 能性が考えられる。

気門封鎖剂は，虫体に付着した薬液が気管系を封鎖して 窒息死させる殺虫剤である(松田ら，1995; 日本植物防疫 協会, 2016）。攵のため，両バイオタイプに同様の防除効 果を期待できることから，バイオタイプ $\mathrm{Q} へ の$ 変遷現象 には影響しないと予想される．現在市販されている気門封 鎖剤の主成分は，界面活性剂，油脂，糖など多様で，固着 性や粘性の強い物質も含まれる。これらの成分が，葉の表 面に付着することで音響信号が変化し，アセチル化グリセ
リドと同様に定位忌避扎よび求愛行動阻害効果を示す可能 性が考えられる。そこで，数種の気門封鎖郕を対象にアセ チル化グリセリドと同様の定位忌避打よび交尾阻害効果の 有無を確認するとともに，より現地の施設栽培条件に近い 環境下に扔いてその効果を検討した結果を以下に記す。

本文に先立ち, 統計处理に有益な助言を賜った農研機構 中央農業研究センターの光永貴之博士に謝意を表する.

\section{材料打よび方法}

\section{1. 供試虫と供試植物}

2015 年に岐皁市内のダイズ戋場から採集した成虫をも とに, 累代飼育したタバココナジラミ個体群を供試した。 餌植物は，ポリエチレン製ポット（直径 $7.5 \mathrm{~cm}$ ）を用いて 本葉が約 5 枚展開した実生栽培トマト（品種：ハウス桃太 郎) とし, 液体肥料 (ハイポネックス 6-10-5, 株式会社八 イポネックスジャパン製) を適宜与えて管理した。飼育は 床面積 $2.9 \mathrm{~m}^{2}(1.7 \mathrm{~m} \times 1.7 \mathrm{~m})$ の恒温室内で行い, 管理条件 は温度 $25^{\circ} \mathrm{C}$, 日長 $14 \mathrm{~L} 10 \mathrm{D}$ とした。試験に必要な個体数 を維持するため，餌植物は劣化に応じて新しいものと交換 した，累代飼育したタバココナジラミ成虫は，杖田・妙楽 （2015）で採用された PCR 法により，バイオタイプ Bであ ることを確認した，累代飼育虫のバイオタイプは，無作為 に採集した 30 頭の成虫を対象に前述の方法で定期的に確 認し，異なるバイオタイプの混入がないことを確認した。

室内試験には，ポリエチレン製ポット（直径 $7.5 \mathrm{~cm} ） を$ 用いて本葉が 3 4 枚展開するまで実生栽培したトマト（品 種：ハウス桃太郎）を用いた。このトマト苗の上位第 2 複 葉と未展開葉以外の葉をすべて切除したものを，供試植物 とした。

\section{2. 薬剤選別試験}

供試剤は，オレイン酸ナトリウム液剤（商品名：オレー 卜液剤，100 倍)，プロピレングリコールモノ脂肪酸エステ ル乳剤 (商品名：アカリタッチ乳剤, 1000 倍), ソルビタ ン脂肪酸エステル (商品名: ムシラップ, 500 倍), 還元澱 粉糖化物液剤 (商品名: エコピタ液剂, 100 倍), 脂肪酸グ リセリド乳剂(商品名：サンクリスタル乳剂，500 倍), 調 合油乳剤 (商品名: サフオイル乳剤, 300 倍), なたね油乳

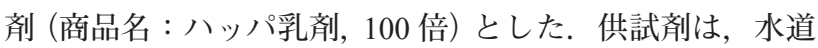
水で所定の倍数に希釈した。希釈倍数は，それぞれの使用 基準に従った。希釈した薬液は，ハンドスプレーを用いて 薬液が葉から滴る程度供試植物に散布した。水道水のみを 散布したものを無処理とした。風乾後，各処理苗を 1 つず つプラスティックトレイ $(23 \mathrm{~cm} \times 32 \mathrm{~cm})$ に入れ，累代飼 育虫の飼育室内に配置した。すなわち，処理苗を入れたプ ラスティックトレイ 8 個を飼育室の中央付近に並べ，タバ ココナジラミ成虫が付着した慨用トマト苗をトレイの周囲 に均等に配置した。プラスティックトレイ 1 個を 1 反復と 
し, 8 反復とした (配置苗の総数: 64). 配置 6 日後, 各処 理苗に定位する成虫数を調査した。また，タバココナジラ ミは求愛行動の第 1 段階で雌雄成虫が並んで定位する（Li et al., 1989) ことから，2 頭の成虫が並んで定位している数 (ペア数) を調査した３頭以上の成虫が並んで定位してい る場合も，ペア数は 1 とした，吸虫管を用いて葉上の成虫 をすべて除去した後，供試植物を実験室に持ち帰り，実体 顕微鏡下で産卵数を調査した。管理条件は，累代飼育虫の 管理条件と同様，温度は $25^{\circ} \mathrm{C}$, 日長は $14 \mathrm{~L} 10 \mathrm{D}$ とした。

\section{3. 効果持続期間}

供試剤は，脂肪酸グリセリド乳剂 $(500$ 倍), 調合油乳 剤 (300 倍)，なたね油乳剤（100 倍）とした。水道水で所 定の濃度に希釈した供試剤は，ハンドスプレーを用いて薬 液が葉から滴る程度供試植物に散布した。試験には，処理 から 1 日，3 日执よび 5 日経過した苗を用いた。水道水を 散布した苗を無处理とし, 散布 1 日後の苗を供試時のみ比 較に用いた。処理苗 1 つをプラスティックケース $(20 \mathrm{~cm} \times$ $20 \mathrm{~cm} \times 20 \mathrm{~cm})$ に入れ，ここにタバココナジラミ成虫を 10 頭 (雌雄 5 頭) 入れたガラスシャーレ（直径 $3 \mathrm{~cm}$, 高さ $1 \mathrm{~cm}$ ）を入れた。 タバココナジラミ成虫は, 低温麻醉後に 面相筆でガラスシャーレに入れ，回復を確認したのちプラ スティックケースに入れた。 シャーレのフタを開けて放 虫したのち，プラスティックケースのフタをして，温度 $25^{\circ} \mathrm{C}$, 日長 $14 \mathrm{~L} 10 \mathrm{D}$ で管理した。放虫 24 時間後, 寄主植 物に定位している成虫数を調査した。 反復は 5 とした。

\section{4. 交尾阻害効果}

累代飼育虫の飼育室から終齢幼虫が付着しているトマト 複葉を採集し，ガラスバイアルに水挿ししたのち透明の円 筒型プラスティックケース（直径 $20 \mathrm{~cm}$, 高さ $8 \mathrm{~cm}$ ）に入 れて室温条件で管理し, 羽化 24 時間以内の雌雄成虫を供 試した，吸虫管で採集した成虫を低温麻酔したのち，面相 筆でガラスシャーレ（直径 $3 \mathrm{~cm}$, 高さ $1 \mathrm{~cm}$ ) に雌雄 5 頭ず つ入れた。雌雄の識別は, 実体顕微鏡下で行った。供試薬 骭は，脂肪酸グリセリド乳剤（500 倍）と調合油乳剤 $(300$ 倍）とした。水道水で所定の濃度に希釈した供試剤は，八 ンドスプレーを用いて薬液が葉から滴る程度供試植物に散 布した。水道水を散布した苗を無処理とし, 散布 2 日後の 苗を試験に用いた。換気用にナイロンゴースを張り付けた 直径 $2 \mathrm{~cm}$ の穴を 2 か所空けた透明プラスティックケース $(20 \mathrm{~cm} \times 20 \mathrm{~cm} \times 20 \mathrm{~cm})$ に，処理苗を 1 個とタバココナジ ラミ成虫を入れたガラスシャーレを入れ，シャーレのフタ を開けて放虫したのち, プラスティックケースのフタをし た. 放虫後, 温度 $25^{\circ} \mathrm{C}$, 日長 $14 \mathrm{~L} 10 \mathrm{D}$ で管理した。放虫 3 日後, 供試植物に定位している成虫数とペア数を調查し, すべての成虫を吸虫管で除去したのち，実体顕微鏡下で葉 裏の産卵数を調査した。さらに, 供試植物を前述の条件で 管理し, 産下卵を飼育した。眼点が確認できるまで幼虫が
発育したら，幼虫が付着する複葉を切除してガラスバイ アルに水插しし，別の透明プラスティックケース $(7 \mathrm{~cm} \times$ $7 \mathrm{~cm} \times 10 \mathrm{~cm})$ に入れて羽化するまで管理した。羽化した 成虫は吸虫管ですべて採集し，70\%エタノールに液浸した のち, 実体顕微鏡下で雌雄を識別して性比を算出した。 ま た，羽化成虫数と産卵数から，羽化率を算出した。 反復は 10 とした。

\section{5. 温室試験}

試験は岐皁県農業技術センター内のガラス温室で実施し た. 供試温室は, 内部が $5.4 \mathrm{~m}^{2}(1.8 \mathrm{~m} \times 3.0 \mathrm{~m})$ の小部屋に 仕切られて打り，側空打よび通路に通じる開口部はすべ て $0.4 \mathrm{~mm}$ 目合いのネットで被覆した。2 2016 年 5 月 31 日 に, 本葉が 5 枚展開するまで実生栽培したトマト苗 (品種 : ホーム桃太郎）を, 各小部屋に 8 株ずつ定植した。 そして, 2016 年 6 月 6 日から約 10 日間隔で，脂肪酸グリセリド乳 郕 500 倍液を 4 回散布した (散布日：2016年 6 月 6 日, 17 日, 28 日打よび 7 月 8 日). 小部屋 1 室を 1 反復とし, 脂 肪酸グリセリド乳剂 500 倍区および無処理区ともに 3 反復 とした。第 1 回散布から第 3 回散布の 1 日後と 6 または 7 日後, 第 4 回散布の 1 日後には, タバココナジラミ成虫 を小部屋 1 室あたり 20 頭放虫した（放虫日：6月 7 日，13 日，18日，23日，29日，7月 5 日打よび 9 日).タバココナ ジラミ成虫は，累代飼育室から吸虫管で採集し，低温麻酔 後に面相筆で雌雄無作為にガラスシャーレ（直径 $3 \mathrm{~cm}$, 高 さ $1 \mathrm{~cm})$ に入れた. 麻酔回復後に各小部屋の中央付近にガ ラスシャーレを配置し，フタを開けて放虫した．各区の全 株全複葉につき, 葉裏に寄生するタバココナジラミ成虫数 と, 2 頭以上の成虫が並んで定位している数 (ペア数) を調 查した。調查は, 1 扎よび 2 回目散布では 2 および 7 また は 8 日後, 3 打よび 4 回目散布では 2 または 3 日後に実施 した (調査日：6月 8 日，14日，19日，24日，30日，7月 11 日)。最終調查時には，各区全株のトマト株につき，中位 にある 3 複葉から 1 枚ずつ小葉を採集して実験室に持ち帰 り，実体顕微鏡下でタバココナジラミの卵数と幼虫数を調 査した。さらに 7 月 20 日には, トマト株からタバココナ ジラミ成虫を吸虫管で採集し，70\%エタノールに液浸した 後, 実体顕微鏡下で雌雄の識別を行い, 性比（雄率：雄/ (雄十雌)）を算出した。採集数は 100 頭以上を原則とし, それに至らない場合は確認できたすべての成虫を採集し た。

\section{6. 統計処理}

薬剤選別試験における定位成虫数, ペア数打よび卵数, 効果持続期間判定試験に打ける定位成虫数は, 1 元配置分 散分析で平均值の差を比較したのち, Tukey 法により薬剤 間の差を比較した。交尾阻害試験における羽化率と性比 (雄率 : 雄 $/($ 雄十雌 $)$ ) は, 角変換後に $t$ 検定で無処理区と の差を比較した。温室試験に打ける産下小葉数, 卵数打よ 
び若齢幼虫数は, $t$ 検定で処理間の差を比較した. 性比（雄 率) は，全反復で出現した総成虫数を用い， $\chi^{2}$ 検定で 2 区 間の差を比較した。

$\chi^{2}$ 検定以外の統計計算には，エクセル統計 ver. 2.15 (BellCurve 製)を用いた。

\section{結果}

\section{1. 薬剤選別試験および効果持続期間}

処理 6 日後のトマト苗上に定位したタバココナジラミ 成虫数は，調合油乳剂区 $(49.6 \pm 20.3$ 頭; 平均土標準偏 差) と脂肪酸グリセリド乳剂区 $(59.8 \pm 23.8$ 頭 $)$ で無処理 区 (100.9 20.8 頭) の半分程度と少ない傾向であったが, すべての区間に有意な差は認められなかった $(d f=7, F=$ 1.863, $p=0.093$; Table 1). タバココナジラミ成虫のペア数 は，脂肪酸グリセリド乳剂区 $(2.1 \pm 1.7$ 組), 調合油乳剂

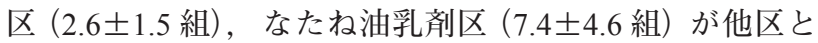
比較して少ない傾向にあり，無処理区や一部の処理区と 有意な差が認められた $(d f=7, F=3.149, p<0.05$; Table 1$)$. 産卵数は，少ないほうから調合油乳剂区 (121.6土34.7 個), 脂肪酸グリセリド乳剂区 $(147.4 \pm 52.3$ 個)，なたね油乳剂 区 (188.5 土66.8 個) の順であったが，ソルビタン脂肪酸エ ステル処理区との間以外に有意な差は認められなかった $(d f=7, F=2.876, p=0.122$; Table 1).

脂肪酸グリセリド乳剂，調合油乳剂，なたね油乳剂の処
理 1 日後のトマト苗に定位した成虫数は，それぞれ $1.4 \pm$ 1.1 頭, $1.8 \pm 0.8$ 頭, $2.2 \pm 1.8$ 頭 (平均士標準偏差) であり, 無処理区 $(6.2 \pm 1.3$ 頭 $)$ と比較して有意に少なかった $(d f=$ $3, F=14.338, p<0.001)$. 各処理区における処理 3 日後打 よび 5 日後の定位成虫数は，いずれも 2 頭程度で処理 1 日 後と大きな差はなく，処理区間でも有意な差は認められ なかった $(3$ 日後: $d f=2, F=1.696, p=0.225,5$ 日後: $d f=2$, $F=0.261, p=0.775$; Table 2).

\section{2. 次世代の性比}

脂肪酸グリセリド乳剂 500 倍希釈液を処理した区では, すべての反復で次世代に雌成虫が出現しなかった。対照 的に，無処理区では 10 回中 8 回の反復で次世代の雌成虫 が出現した。無処理区における次世代の性比（雄率：雄／ (雄十雌)）は $0.68 \pm 0.26$ (平均土標準偏差) であり, 脂肪 酸グリセリド乳剂処理区よりも有意に低かった(角変換後 $t$ 検定, $t=4.718, p<0.001$; Table 3$)$. 羽化した総成虫数は, 脂肪酸グリセリド乳剤処理区 (98 頭) が無処理区 (239 頭) より少なかった。羽化率はそれぞれ $82.9 \pm 22.3 \%$ および $92.7 \pm 41.9 \%$ であり, 有意な差はなかった（角変換後 $t$ 検定， $t=0.054, p=0.958$; Table 3 ).

調合油乳剂 300 倍希釈液を処理した区では, 10 反復中 1 反復で次世代に雌成虫が出現した。 対照的に, 無処理区で はすべての反復で次世代に雌成虫が出現した。調合油乳 骫における次世代の性比 (雄率) は $0.90 \pm 0.17$ で，無処理

Table 1. Numbers of oriented adults, courting pairs, and eggs of Bemisia tabaci on the treated tomato plants

\begin{tabular}{lcrcc}
\hline \multicolumn{1}{c}{ Pesticide } & Dilution & $\begin{array}{c}\text { Number of oriented } \\
\text { adults }\end{array}$ & Number of courting pairs & Number of eggs \\
\hline Sodium oleate & 100 & $84.3 \pm 21.3 \mathrm{a}$ & $19.1 \pm 5.9 \mathrm{ab}$ & $261.8 \pm 82.3 \mathrm{ab}$ \\
Propylene glycol esters of fatty acids & 1000 & $124.3 \pm 23.3 \mathrm{a}$ & $25.3 \pm 5.1 \mathrm{~b}$ & $322.6 \pm 55.4 \mathrm{ab}$ \\
Sorbic acid esters of fatty acids & 500 & $116.5 \pm 25.8 \mathrm{a}$ & $25.5 \pm 7.2 \mathrm{~b}$ & $516.3 \pm 130.3 \mathrm{~b}$ \\
Hydrogenated starch hydrolysate & 100 & $76.9 \pm 15.8 \mathrm{a}$ & $14.4 \pm 4.0 \mathrm{ab}$ & $288.9 \pm 80.3 \mathrm{ab}$ \\
Decanoyloctanoylglycerol & 500 & $59.8 \pm 23.8 \mathrm{a}$ & $2.1 \pm 1.7 \mathrm{a}$ & $147.4 \pm 52.3 \mathrm{a}$ \\
Safflower and cotton oil & 300 & $49.6 \pm 20.3 \mathrm{a}$ & $2.6 \pm 1.5 \mathrm{a}$ & $121.6 \pm 34.7 \mathrm{a}$ \\
Rape seed oil & 200 & $93.1 \pm 35.4 \mathrm{a}$ & $7.4 \pm 4.6 \mathrm{a}$ & $188.5 \pm 66.8 \mathrm{a}$ \\
Control (water) & - & $100.9 \pm 20.8 \mathrm{a}$ & $21.4 \pm 6.1 \mathrm{~b}$ & $279.4 \pm 43.7 \mathrm{ab}$ \\
\hline
\end{tabular}

Examination was conducted six days after treatment. Values are presented as mean \pm SD. Values in the same column with the same letters are not significantly different (Tukey's post hoc test, $p>0.05$ ).

Table 2. Changes in the number of oriented adults of $B$. tabaci on tomato leaflets after treatment

\begin{tabular}{lcccc}
\hline \multirow{2}{*}{ Pesticide } & Dilution & \multicolumn{3}{c}{ Number of oriented adults } \\
\cline { 3 - 5 } & & 1 & 3 & 5 (day after treatment) \\
\hline Decanoyloctanoylglycerol & 500 & $1.4 \pm 1.1 \mathrm{a}$ & $3.0 \pm 1.6 \mathrm{a}$ & $2.2 \pm 1.1 \mathrm{a}$ \\
Safflower and cotton oil & 300 & $1.8 \pm 0.8 \mathrm{a}$ & $2.6 \pm 1.3 \mathrm{a}$ & $2.6 \pm 0.9 \mathrm{a}$ \\
Rape seed oil & 100 & $2.2 \pm 1.8 \mathrm{a}$ & $1.6 \pm 0.5 \mathrm{a}$ & $2.4 \pm 0.5 \mathrm{a}$ \\
Control (water) & - & $6.2 \pm 1.3 \mathrm{~b}$ & - & - \\
\hline
\end{tabular}

Values are presented as mean \pm SD. Values in the same column with the same letters are not significantly different (Tukey's post hoc test, $p>0.05$ ) . 
Table 3. Numbers of courting pairs, emergence ratio, and progeny sex ratio in the splayed and control cohorts

\begin{tabular}{|c|c|c|c|c|c|c|}
\hline Pesticide & Dilution & Replicate & $\begin{array}{c}\text { Number of } \\
\text { courting pairs }\end{array}$ & $\begin{array}{c}\text { Emergence ratio }^{\mathrm{a}} \\
(\%)\end{array}$ & $\begin{array}{l}\text { Total number of } \\
\text { emerged adults }\end{array}$ & $\begin{array}{c}\text { Sex ratio }^{\mathrm{a}} \\
(\mathrm{male} /(\text { male }+ \text { female }))\end{array}$ \\
\hline Decanoyloctanoylglycerol & 500 & $10(0)$ & $0 \pm 0$ & $82.9 \pm 22.3 \mathrm{a}$ & 98 & $1 \pm 0 \mathrm{~b}$ \\
\hline Control (water) & - & $10(8)$ & $1.0 \pm 1.2$ & $92.7 \pm 41.9 \mathrm{a}$ & 239 & $0.68 \pm 0.26 \mathrm{a}$ \\
\hline Safflower and cotton oil & 300 & $10(1)$ & $0 \pm 0$ & $81.8 \pm 15.5 \mathrm{a}$ & 68 & $0.90 \pm 0.17 b$ \\
\hline Control (water) & - & $10(10)$ & $0.6 \pm 0.8$ & $98.7 \pm 23.6 \mathrm{a}$ & 214 & $0.76 \pm 0.16 \mathrm{a}$ \\
\hline
\end{tabular}

${ }^{a}$ Values in these columns indicate the data of emerged whitefly progeny.

Values are presented as mean $\pm \mathrm{SD}$. Values in the same column with the same letters are not significantly different $(t$-test after arcsine transformation, $p>0.05)$. Numbers in parentheses indicate the number of replicates in which adult females emerged.

Table 4. Numbers of leaflets oviposited on, eggs, larvae, and the progeny sex ratio of B. tabaci

\begin{tabular}{lccccc}
\hline \multicolumn{1}{c}{ Pesticide } & Dilution & $\begin{array}{c}\text { Number of leaflets } \\
\text { oviposited on }\end{array}$ & $\begin{array}{c}\text { Number of eggs } \\
\text { per 24 leaflets }\end{array}$ & $\begin{array}{c}\text { Number of larvae } \\
\text { per 24 leaflets }\end{array}$ & $\begin{array}{c}\text { Progeny sex ratio } \\
\text { (male/(male }+ \text { female) })\end{array}$ \\
\hline $\begin{array}{l}\text { Decanoyloctanoylglycerol } \\
\text { Control (water) }\end{array}$ & 500 & $2 \pm 0 \mathrm{a}$ & $6.3 \pm 6.1 \mathrm{a}$ & $3.0 \pm 1.7 \mathrm{a}$ & $0.46 \pm 0.03 \mathrm{~b}$ \\
& - & $12.5 \pm 4.7 \mathrm{~b}$ & $54.25 \pm 10.3 \mathrm{~b}$ & $42.0 \pm 25.9 \mathrm{~b}$ & $0.33 \pm 0.03 \mathrm{a}$ \\
\hline
\end{tabular}

Values are presented as mean $\pm \mathrm{SD}$. Values in the same column with the same letters are not significantly different $[t$-test (numbers of leaflets, eggs, and larvae) or chi-square test (progeny sex ratio), $p>0.05]$.

区 $(0.76 \pm 0.16)$ よりも有意に高かった（角変換後 $t$ 検定， $t=5.872, p<0.001$; Table 3$)$. 羽化した総成虫数は, 調合油 乳剤処理区 (68 頭) が無処理区 (214 頭) より少なかった. 羽化率はそれぞれ $81.8 \pm 15.5 \%$ および $98.7 \pm 23.6 \%$ であり， 有意な差はなかった（角変換後 $t$ 検定, $t=0.599, p=0.563$; Table 3).

\section{3. 温室試験}

タバココナジラミ成虫は，いずれの区でも調查開始時 から認められ，調査終了時にかけて増加する傾向であっ た。すへてて調査において，脂肪酸グリセリド乳剂 500 倍 液を散布した区の成虫数は，無処理区よりも少なかった. 第 1 回散布の 18 日後となる 6 月 24 日以降，無処理区の成 虫数は指数関数的に増加したが $(6$ 月 24 日: 42.0 頭, 6 月 30 日：123.7 頭，7月 11 日：530.7 頭)，散布区に打ける増 加の程度は緩やかな直線的であった（6月24日：18.7頭, 6月 30 日：23.3 頭，7月 11 日：58.3 頭； Fig. 1)。無処理区 に抢けるタバココナジラミ成虫のペアは, 2 回目の調査以 降すべての調査で認められ，成虫数の増加に伴いペア数が 増加する傾向であった。一方，散布区に打ける成虫のペア は, 6 月 14 日の第 2 回調查時に 1 組認められたものの, そ れ以外の調査では認められなかった (Fig. 1)。最終調查時 に採集した 24 小葉あたりの産卵数は，無処理区で $54.3 \pm$ 10.3 個 (平均土標準偏差), 散布区では $6.3 \pm 6.1$ 個であり, 両区の間には有意な差が認められた $(t$ 検定, $t=3.873, p=$ 0.012; Table 4). 幼虫数は, 無処理区で $42.0 \pm 25.9$ 頭, 散 布区では $3.0 \pm 1.7$ 頭であり，産卵数と同様，両区の間に は有意な差が認められた $(t$ 検定, $t=4.019, p=0.010$; Table
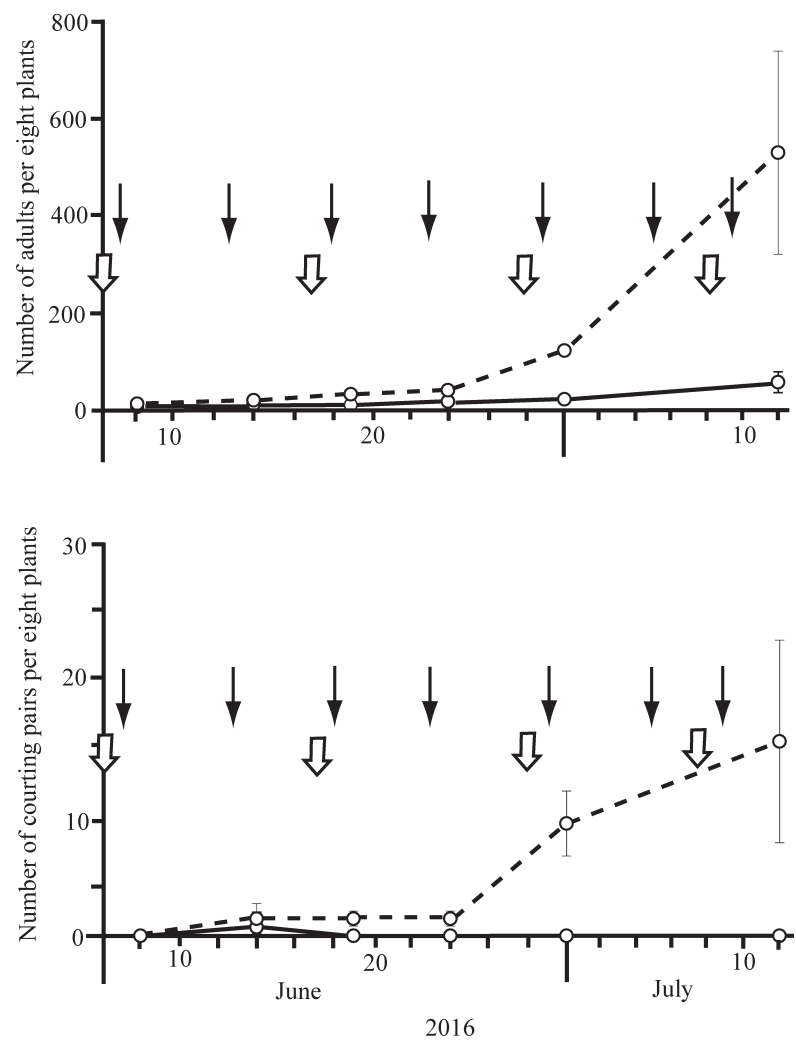

Fig. 1. Changes in the numbers of B. tabaci adults and courting pairs on tomato plants treated with 500 -fold diluted decanoyloctanoylglycerol solution (sprayed cohort: solid line) or left untreated (control: broken line). Points and vertical bars represent mean values and standard deviations, respectively. White and black arrows indicate the spray and whitefly release days, respectively. 
4)。採集した成虫の性比（雄率：雄／(雄十雌））は，無処 理区では $0.33 \pm 0.03$ と雌に偏っていたが，散布区では 0.46 \pm 0.03 で雌雄ほぼ同数であり, 両区間の性比 (雄率) に は有意な差が認められた $\left(\chi^{2}\right.$ 検定, $\chi_{\text {cal }}^{2}=7.589, p<0.01$; Table 4).

\section{考察}

本研究で供試した 7 種の気門封鎖剤のうち，脂肪酸グリ セリド乳剤，調合油乳郕，およびなたね油乳刜を散布した トマト苗では，処理 6 日後に定位するタバココナジラミ成 虫数と産卵数は他剤を散布した区や無処理区と比較して少 ない傾向にあり，ペア数は他区と比較して有意に少なかっ た（Table 1). 近年，アセチル化グリセリドを散布した卜 マトに打いて，タバココナジラミバイオタイプ B 扎よび $\mathrm{Q}$ 成虫の定位数, ペア数, 産卵数が減少することから, 成 虫の定位阻害，産卵抑制，交尾阻害効果を持つと報告さ れている (Kashima et al., 2014)。前述の結果は，この報告 と概ね同様の傾向であると考えられる. タバココナジラミ は，求愛行動の第 1 段階で雄成虫が雌成虫に並んで定位す る (Li et al., 1989)。本研究において, 脂肪酸グリセリド乳 䎟や調合油乳剂を散布したトマト苗に処女雌成虫と雄成虫 を放虫したところ，並んで定位する個体は確認できなかっ た（Table 3)。ささらに，産下卵を成虫まで発育させた結 果，脂肪酸グリセリドを散布した区からは雌成虫が出現せ ず，調合油乳剤を散布した区からは 10 反復中 1 回だけ雌 成虫が出現した（Table 3)。対照的に，水のみを散布した 区からは 10 反復中 10 回または 8 回雌成虫が出現した。両 剤を散布したトマトで発育した次世代の性比（雄率：雄／ (雄十雌)）は，無処理区と比べて高い傾向にあった（Table 3)。脂肪酸グリセリド乳剂や調合油乳剤を散布した区の 羽化率は無処理区と差がなかったことから（Table 3), 脂 肪酸グリセリドや調合油乳剤を散布した植物上で雌に発育 する個体だけが死亡したとは考えにくい，タバココナジラ ミは半数倍数性であり，受精卵から雌が，未受精卵からは 雄が発育する (Byrne and Berrows, 1991)。したがって, 脂 肪酸グリセリド乳剤や調合油乳剤の散布により, タバココ ナジラミの正常な交尾が阻害され，未受精卵から発育する 雄成虫が多く出現したと考えられる．以上のことから，脂 肪酸グリセリド乳剤と調合油乳剂は，アセチル化グリセリ ドと同様，植物に散布することでタバココナジラミ成虫の 定位抑制，それに伴う産卵数の減少，求愛行動抑制といっ た効果を有すると考えられる.

施設内で栽培されるトマトなどの農作物では，外部から 施設内に侵入したタバココナジラミ成虫が植物に定位・産 卵し，繁殖することで施設内の密度が上昇すると考えられ る. 本研究では, 温室内のトマトに脂肪酸グリセリド乳剤 を 10 日間隔で散布し，散布 1 日後と 6 または 7 日後にタ
バココナジラミ成虫を放虫した。年の結果，散布区の葉 上に打ける定位成虫数は, 無処理区よりも少なく推移し た (Fig. 1)。ささらに，最終調査時に打ける散布区の産卵数 と幼虫数は，無処理区よりも少なかった（Table 4)。本研 究の室内試験では，脂肪酸グリセリド乳剂処理区における 産卵数は，調合油乳剂処理区に次いで，他剤処理区よりも 少ない傾向であった（Table 1)。脂肪酸グリセリド乳剤な どの気門封鎖彨は，虫体に付着した薬液が気管系を封鎖し て窒息死させるとされている（松田ら，1995; 日本植物防 疫協会, 2016)。コナジラミ類の幼虫は，微小なうえに葉 の表面で固着生活しているため，気門封鎖剤による防除効 果を得やすいかもしれない. 対照的に, タバココナジラミ 成虫は飛翔による移動が可能なうえ, 本研究では脂肪酸グ リセリド乳剤の散布後に放虫しているため，気門封鎖剤 により死亡する個体は多くないと予想される。特に，散 布 6 または 7 日後に放虫した個体は，脂肪酸グリセリド乳 剤散布の直接的な致死効果で死亡したとは考えにくい。こ 机らのことから, 本研究では産卵数の減少と幼虫の死亡 が，脂肪酸グリセリド乳剂散布による密度抑制効果の主要 因と考えられる。一方，求愛行動の第 1 段階である雌雄成 虫が並んで定位するぺア数は，無处理区では成虫数の増加 に伴い増加する傾向であったが，散布区では 6 回の調査 で1組認められただけであった (Fig. 1)。最終調査時にお けるタバココナジラミ成虫の性比 (雄率 : 雄/(雄十雌 $)$ ) は，散布区ではほぼ 0.5 (雌雄同数) であったが, 無処理区 では 0.33 で雌が多かった（Table 3)。本研究では，最初の 放虫から 34 日後に性比の調査を行った。 トマトに打ける タバココナジラミバイオタイプ B の卵から成虫までの発 育期間は, $25^{\circ} \mathrm{C}$ で 21 日, $30^{\circ} \mathrm{C}$ で 18 日程度である (Tsueda and Tsuchida, 2011) ことから，性比調査時の成虫には放虫 した成虫の次世代が含まれていると考えられる。これらの ことから，散布区に打ける性比 (雄率) の上昇は，脂肪酸 グリセリド乳剂の散布により放虫した成虫の交尾が阻害さ れ，未受精卵から発育した雄成虫が多く含まれた可能性が ある，本研究では，累代飼育室で無作為に採集した成虫を 供試して打り，放虫個体には性別，羽化日齢，交尾経験の 異なるものが混在すると考えられる。このことは，実際の 生産現場に打いて野外から施設内に侵入するタバココナジ ラミ成虫の条件に近いと思われる。したがって，現地围 場でも脂肪酸グリセリド乳剂散布による成虫の交尾阻害, 次世代以降の性比の上昇が期待できる。一般に，性比（雄 率) の上昇は，個体群の繁殖力の低下につながると考えら れる. 以上のことから，脂肪酸グリセリド乳剤を定期的に 散布すれば，殺虫効果に加え，タバココナジラミ成虫の定 位阻害, 産卵数減少打よび交尾行動阻害に伴う性比の上昇 により，タバココナジラミの密度を抑制できると考えられ る. 
これまでに，アセチル化グリセリドは，タバココナジ ラミバイオタイプ B および $\mathrm{Q}$ に対し, 成虫の定位阻害, 産卵抑制，交尾阻害効果を持つことが報告されている (Kashima et al., 2014, 2016)．アセチル化グリセリドは，モ ノまたはジアセチルグリセロールに分類される油脂であ る。また，本研究で用いた脂肪酸グリセリド乳剂，調合油 乳剤およびなたね油乳剂は，いずれも油脂を主成分とする 気門封鎖剤である。したがって，油脂を主成分とする気門 封鎖剤は，上記効果を有する可能性がある。今後は，上記 効果のメカニズム解明，これらの薬剤を利用した防除体系 の検討を行う必要がある.

\section{摘 要}

タバココナジラミは，施設栽培の野菜類などに深刻な被 害を与える害虫である。気門封鎖剤の脂肪酸グリセリド乳 剂, 調合油乳剤およびなたね油乳剂を散布したトマト苗で は, 処理 6 日後のタバココナジラミの雌雄成虫が並んで定 位するペア数は，他の気門封鎖剂を散布したトマトよりも 少なかった。脂肪酸グリセリド乳剂および調合油乳剂を散 布したトマト苗に処女雌成虫と雄成虫を放虫したところ, 出現した次世代成虫の性比は雄に偏った。温室に定植した トマト株に脂肪酸グリセリド乳剂を 10 日間隔で散布し, 散布後にタバココナジラミ成虫を放虫したところ, 散布区 における葉上の成虫数とぺア数は無処理区と比較して少な く推移し, 産卵数と幼虫数は有意に少なかった. 最初の散 布から約 1 か月後, 散布区に打ける成虫の性比 (雄率) は, 無処理区よりも高かった，以上のことから，油脂を有効成 分とする気門封鎖剂である脂肪酸グリセリド乳剂, 調合油 乳剤およびなたね油乳剤は，タバココナジラミ成虫の定位 阻害や交尾阻害をもたらす効果を有しており，一定間隔で 散布すれば，これらの効果によりタバココナジラミ密度を 低く抑制できると考えられた。

\section{引用文 献}

Bedford, I. D., R. W. Briddon, J. K. Brown, R. C. Rosell and P. G. Markham (1994) Geminivirus transmission and biological characterization of Bemisia tabaci (Gennadius) biotypes from different geographic regions. Ann. Appl. Biol. 125: 311-325.

Brown, J. K. (2000) Molecular markers for the identification and global tracking of whitefly vector-Begomovirus complexes. Virus Res. 71: 233-260.

Brown, J. K. and J. Bird (1992) Whitefly-transmitted geminiviruses and associated disorders in the Americas and the Caribbean Basin. Plant Dis. 76: 220-225.

Byrne, D. N. and T. S. Berrows Jr. (1991) Whitefly biology. Ann. Rev. Entomol. 36: 431-457.

Chu, D., Y. J. Zhang and F. H. Wan (2010) Cryptic invasion of the exotic Bemisia tabaci biotype Q occurred widespread in Shandong
Province of China. Fla. Entomol. 93: 203-207.

Costa, H. S. and J. K. Brown (1991) Variation in biological characteristics and esterase patterns among populations of Bemisia tabaci and the association of one population with silverleaf symptom induction. Entomol. Exp. Appl. 61: 211-219.

Crowder, D. W. et al. (2010) Mating behavior, life history and adaptation to insecticides determine species exclusion between whiteflies. J. Anim. Ecol. 79: 563-570.

De Barro, P. J., S. S. Liu, L. M. Boykin and A. Dinsdale (2011) Bemisia tabaci : a statement of species status. Ann. Rev. Entomol. 56:1-19.

Dennehy, T. J. et al. (2010) Extraordinary resistance to insecticides reveals exotic Q biotype of Bemisia tabaci in the New World. J. Econ. Entomol. 103: 2174-2176.

Dinsdale, A., L. Cook, C. Riginos, Y. M. Buckley and P. De Barro (2010) Refined global analysis of Bemisia tabaci (Hemiptera: Sternorrhyncha: Aleyrodoidea: Aleyrodidae) mitochondrial cytochrome oxidase 1 to identify species level genetic boundaries. Ann. Entomol. Soc. Am. 103: 196-208.

樋口聡志 ·前田美佐 ·行徳 裕 ·上田重文・ 小牧孝一 (2007) 熊本県に発生しているタバココナジラミのバイオタイプ 分布と季節的変動. 九病虫研会報 53: 59-65. [Higuchi, S., M. Maeda, Y. Gyoutoku, S. Ueda and K. Komaki (2007) Distribution and seasonal fluctuations in the population of different biotypes of Bemisia tabaci (Gennadius) in Kumamoto Prefecture. Kyushu Pl. Prot. Res. 53: 59-65.]

本多健一郎 (2005) トマト黄化葉巻病と媒介コナジラミをめぐ る最近の研究情勢. 植物防疫 59：299-304. [Honda, K. (2005)

Recent advances on researches of tomato yellow leaf curl and its vector whitefly. Plant Prot. 59: 299-304.]

本多健一郎 (2008) トマト黄化葉巻病及びタバココナジラ ミ・バイオタイプ Qの発生状況と防除の取り組み. 今月 の農業 52(3)：17-22. [Honda, K. (2008) “Distribution and elimination of tomato yellow leaf curl disease and Bemisia tabaci Q-biotype." Japan Agricultural Technology 52 (3) : 17-22.]

Horowitz, A. R., I. Denholm, K. Gorman, J. L. Cenis, S. Kontsedalov and I. Isyaaya (2003) Biotype Q of Bemisia tabaci identified in Israel. Phytoparasitica 31: 94-98.

Hussey, N. W., W. J. Parr and B. Gurney (1958) The effect of whitefly populations on the cropping of tomatoes. Ann. Rep. Glasshouse Crops Res. Inst. 7: 79-103.

Kashima, T., C. Takeda, N. Akiyoshi, K. Yoshida and Y. Arimoto (2014) Effect of a novel repellent, acetylated glyceride, against sweet potato whitefly, Bemisia tabaci (Gennadius) (Hemiptera: Aleyrodidae). J. Pestic. Sci. 39: 91-97.

Kashima, T., K. Kanmiya, K. Yoshida and Y. Arimoto (2016) Effect of a novel repellent, acetylated glyceride, on courtship behaviors and acoustic signals of Bemisia tabaci. J. Appl. Entomol. 140: $11-18$.

Li, T. Y., S. B. Vinson and D. Gerling (1989) Courtship and mating behavior of Bemisia tabaci (Homoptera: Aleyrodidae). Environ. Entomol. 18: 800-806.

松田径央・宮田哲至・高木康至 (1995) オレイン酸ナトリウ ム液剤の殺虫効果とそのメカニズム。植物防疫 49：50-53. 
[Matsuda, M., T. Miyata and Y. Takagi (1995) Insecticidal activities and mechanism of sodium oleate. Plant Prot. 49: 50-53.]

松井正春 (1992) タバココナジラミの吸汁によるトマト果実の 着色異常. 応動昆 36：47-49. [Matsui, M. (1992) Irregular ripening of tomato fruit caused by the sweetpotato whitefly, Bemisia tabaci (Gennadius) in Japan. Jpn. J. Appl. Entomol. Zool. 36: 47-49.]

日本植物防疫協会(編) (2016) 農薬ハンドブック 2016 年版. 日本植物防疫協会, 東京. 1089 pp. [Japan Plant Protection Association (ed.) (2016) The Handbook of Agricultural Pesticides ver. 2016. Japan Plant Protection Association, Tokyo. 1089 pp. ]

大戸謙二 (1990) タバココナジラミの発生とその見分け方. 植 物 防疫 44:264-266. [Ohto, K. (1990) Occurrence of the sweetpotato whitefly, Bemisia tabaci Gennadius, on the poinsettia. Plant Prot. 44: 264-266.]

大井田寛 - 津金扸昭 - 久保周子 - 草川知行 - 清水喜一 - 野々宮 弘明・風戸治子・中臺敬子（2007） 千葉県におけるタバコ コナジラミバイオタイプ Qの発生状況および物理的防除法 の検討. 関東病虫研報 54: 143-150. [Oida, H., T. Tsugane, C. Kubo, T. Kusakawa, K. Shimizu, H. Nonomiya, N. Kazato and K. Nakadai (2007) Distribution, seasonal occurrence and physical control of sweet potato whitefly Bemisia tabaci (Homoptera: Aleyrodidae) Q-biotype in Chiba Prefecture. Ann. Rept. Kanto Pl. Prot. Soc. 54: 143-150.]

Oliveria, M. R. V., T. J. Henneberry and P. Anderson (2001) History, current status, and collaborative research projects for Bemisia tabaci. Crop Prot. 20: 709-723.

Perring, T. M. (2001) The Bemisia tabaci species complex. Crop Prot. 20: 725-737.

Schuster, D. J., T. F. Mueller, J. B. Kring and J. F. Price (1990) Relationship of the sweetpotato whitefly to a new tomato fruit disorder in Florida. Hortscience 25: 1618-1620.

Simón, B., E. Moriones, C. Soria, F. Beitia, D. Bosco and J. L. Cenis
(1999) Variación genética de problaciones de Bemisia tabaci (Gennadius) en la Cuenca Mediterranéa occidental. Resúmenes del Congreso Nacional de Entomología Aplicada. Jornadas Científicus de la Sociedad Española de Entomología Aplicada, Aguadulce, Spain. Juta de Andalucia, p. 20.

Sun, D. B., Y. Q. Liu, L. Qin, J. Xu, F. F. Li and S. S. Liu (2013) Competitive displacement between two invasive whiteflies: insecticide application and host plant effects. Bul. Entomol. Res. 103: 344-353.

杖田浩二・妙楽 崇 (2015) 殺虫剤の土壤処理がタバココナジ ラミ(カメムシ目：コナジラミ科) バイオタイプ B 打よび Q の個体群比率に与える影響. 応動昆 59：133-137. [Tsueda, T. and T. Taera (2015) The impact of insecticide soil treatment to the ratio of biotype $\mathrm{B}$ and $\mathrm{Q}$ populations of Bemisia tabaci (Hemiptera: Aleyrodidae). Jpn. J. Appl. Entomol. Zool. 59: 133-137.]

Tsueda, H. and K. Tsuchida (2011) Reproductive differences between $\mathrm{Q}$ and B whiteflies, Bemisia tabaci, on three host plants and negative interactions in mixed cohorts. Entomol. Exp. Appl. 141: 197-207.

Ueda, S. and J. K. Brown (2006) First report of the Q biotype of Bemisia tabaci in Japan by mitochondrial cytochrome oxidase I sequence analysis. Phytoparasitica 34: 405-411.

Xu, J., P. J. De Barro and S. S. Liu (2010) Reproductive incompatibility among genetic groups of Bemisia tabaci supports the proposition that the whitefly is a cryptic species complex. Bull. Entomol. Res. 100: 359-366.

Yee, W. L., N. C. Toscano, C. C. Chu, T. J. Henneberry and R. L. Nichols (1996) Bemisia argentifolii (Homoptera: Aleyrodidae) action thresholds and cotton photosynthesis. Environ. Entomol. 25: 1267-1273.

Yokomi, R. K., K. A. Hoelmer and L. S. Osborne (1990) Relationship between the sweetpotato whitefly and the squash silverleaf disorder. Phytopathology 80: 895-900. 